\title{
VAPORIZATION BEHAVIOR OF TETRAOCTYLPHOSPHONIUM BIS(2-ETHYLHEXYL)PHOSPHATE IONIC LIQUID
}

\author{
JW McMurray, Y Zhou, HM Luo, and J Qu
}

\begin{abstract}
A B S T R A C T
The equilibrium vapor pressures, $p_{e}$, of the ionic liquid tetraoctylphosphonium bis(2ethylhexyl)phosphate ([ $\left.\left.\mathrm{P}_{8888}\right][\mathrm{DEHP}]\right)$ over the temperature range $409-495 \mathrm{~K}$ were determined for the first time using mass loss Knudsen effusion. The $p_{e}$ versus temperature relationship compares well to 1-methyl-3-octylimidazolium bis(trifluoromethylsulfonyl)imide $\left(\left[\mathrm{C}_{8} \mathrm{mim}\right]\left[\mathrm{NTf}_{2}\right]\right)$ but is lower than that of 1-ethyl-3-methylimidazolium bis(trifluoromethylsulfonyl)imide $\left(\left[\mathrm{C}_{2} \mathrm{mim}\right]\left[\mathrm{NTf}_{2}\right]\right)$ when measured using the same technique. The discrepancies between the $p_{e}$ determined in this work for $\left[\mathrm{C}_{8} \mathrm{mim}\right]\left[\mathrm{NTf}_{2}\right]$ and $\left[\mathrm{C}_{2} \mathrm{mim}\right]\left[\mathrm{NTf}_{2}\right]$ with previous studies is discussed. The enthalpy and entropy of vaporization for all three fluids are estimated from the Clasius-Clapeyron relation.
\end{abstract}

This manuscript has been authored by UT-Battelle, LLC under Contract No. DE-AC05-00OR22725 with the U.S. Department of Energy. The United States Government retains and the publisher, by accepting the article for publication, acknowledges that the United States Government retains a nonexclusive, paid-up, irrevocable, world-wide license to publish or reproduce the published form of this manuscript, or allow others to do so, for United States Government purposes. The Department of Energy will provide public access to these results of federally sponsored research in accordance with the DOE Public Access Plan (http://energy.gov/downloads/doe-public-access-plan). 


\section{Introduction}

An ionic liquid (IL) is a molten salt and the variation of cationic and anionic structures, along with their numerous combinations make ILs flexible in molecular design. Recent experimental determinations of equilibrium vapor pressure, $p_{e}$, below $500 \mathrm{~K}$ for ILs using mass loss Knudsen effusion and transpiration type measurements [1-3] show that low $p_{e}$ are among ILs' unique physicochemical properties. This is key for potential applications including electrochemistry, chemical synthesis, catalysis, lubrication, etc. [4-6] and excellent descriptions on the current state of the field of bulky cations and anions can be found in [7-16]. Further, it has been pointed out by Bier and Dietrich [17] that ILs do not evaporate significantly even under ultrahigh vacuum (UHV). While this can be attributed to low $p_{e}$, it is also consequence of a low vaporization coefficient, $\alpha$. Previous experimental $p_{e}$ have assumed $\alpha$ values of unity $[1,2]$.

Specifically, phosphonium-phosphate ILs have recently been reported as effective oilsoluble anti-wear lubricant additives [18, 19]. However, their vapor liquid equilibrium (VLE) behavior has not been characterized. Here, we measure $p_{e}$ with temperature using mass loss Knudsen effusion for tetraoctylphosphonium bis(2-ethylhexyl)phosphate $\left(\left[\mathrm{P}_{8888}\right][\mathrm{DEHP}]\right)$ along with two baseline ILs, 1-ethyl-3-methylimidazolium bis(trifluoromethylsulfonyl)imide $\left(\left[\mathrm{C}_{2} \mathrm{mim}\right]\left[\mathrm{NTf}_{2}\right]\right)$ and 1-methyl-3-octylimidazolium bis(trifluoromethylsulfonyl)imide $\left(\left[\mathrm{C}_{8} \mathrm{mim}\right]\left[\mathrm{NTf}_{2}\right]\right)$. The results for $\left[\mathrm{C}_{8} \mathrm{mim}\right]\left[\mathrm{NTf}_{2}\right]$ and $\left[\mathrm{C}_{2} \mathrm{mim}\right]\left[\mathrm{NTf}_{2}\right]$ are compared to those from previous studies[2, 3] while $p_{e}$ with temperature, $T$, relationship is reported here for the first time for $\left[\mathrm{P}_{8888}\right][\mathrm{DEHP}]$ between $409-495 \mathrm{~K}$. Further, $\alpha$ is calculated and estimates for the entropy and enthalpy of vaporization for all three ILs are given for the average $T$ of the measurements.

\section{Experimental}

\section{Sample preparation}

All reagents and solvents were of the highest grade commercially available and were used without further purification. The ILs studied consist of the 1-n-alkyl-3methylimidazolium cation $\left[\mathrm{C}_{\mathrm{n}} \mathrm{mim}\right]$, where $\mathrm{n}$ is 2 or 8 , the number of carbon atoms in the alkyl chain), paired with bis(trifluoromethanesulfonyl)amide, [ $\left.\mathrm{NTf}_{2}{ }^{-}\right]$. These ILs were prepared following methods detailed in the literature [20]. Tetraoctylphosphonium bis(2ethylhexyl)phosphate ([ $\left.\left.\mathrm{P}_{8888}\right][\mathrm{DEHP}]\right)$ was prepared according to our previous published paper[21]. The structures for each IL are presented in Fig. 1.

\section{[Figure 1 here]}

$\left[\mathrm{C}_{2} \mathrm{mim}\right]\left[\mathrm{NTf}_{2}\right]$ and $\left[\mathrm{C}_{8} \mathrm{mim}\right]\left[\mathrm{NTf}_{2}\right]$ were synthesized via modified procedure and metathesis reactions as described in [20,22]. Equal mole ratio of 1-methylimidazole and bromoethane or 1-bromooctane were mixed at room temperature and stirred over a period of time and the reaction was monitored with $\mathrm{NMR}$, the obtained $\left[\mathrm{C}_{2} \mathrm{mim}\right] \mathrm{Br}$ or $\left[\mathrm{C}_{8} \mathrm{mim}\right] \mathrm{Br}$ was then dissolved in D.I. $\mathrm{H}_{2} \mathrm{O}$ and was added $\mathrm{LiNTf}_{2}$ aqueous solution at 60 
${ }^{\mathrm{O}} \mathrm{C}$, stirred for 2 hours. The lower organic phase was separated and the upper aqueous phase was extracted with dichloromethane three times. The combined organic phases were washed with D.I. $\mathrm{H}_{2} \mathrm{O}$ four times to ensure removal of $\mathrm{NaBr}$. Solvents were distilled off by rotary evaporator and the product was dried at $70{ }^{\circ} \mathrm{C}$ under vacuum for $4 \mathrm{~h}$ to yield $\left[\mathrm{C}_{2} \mathrm{mim}\right]\left[\mathrm{NTf}_{2}\right]$ or $\left[\mathrm{C}_{8} \mathrm{mim}\right]\left[\mathrm{NTf}_{2}\right]$ as a colorless liquid.

For synthesis of [ $\left.\mathrm{P}_{8888}\right]$ [DEHP] [19], tetraoctylphosphonium bromide ([ $\left.\mathrm{P}_{8888}\right] \mathrm{Br}, 40.58 \mathrm{~g}$, $72.0 \mathrm{mmol}$ ) and Di(2-ethylhexyl)phosphoric acid (HDEHP, $23.2 \mathrm{~g}, 20.2 \mathrm{mmol}$ ) were mixed in $90 \mathrm{~mL}$ of deionized water (D.I. $\mathrm{H}_{2} \mathrm{O}, 18.2 \mathrm{M} \Omega-\mathrm{cm}$ ) and $100 \mathrm{~mL}$ of hexanes. A solution of sodium hydroxide ( $\mathrm{NaOH}, 2.88 \mathrm{~g}, 72.0 \mathrm{mmol}$ ) in $100 \mathrm{~mL}$ of D.I. $\mathrm{H}_{2} \mathrm{O}$ was added drop wise at room temperature to this stirred suspension which became clear after the addition of $\mathrm{NaOH}$ was completed. The mixture continued to be stirred at room temperature overnight. The upper organic phase was separated and washed with D.I. $\mathrm{H}_{2} \mathrm{O}$ four times to ensure removal of $\mathrm{NaBr}$. Solvents were distilled off by rotary evaporator and the product was dried at $70{ }^{\circ} \mathrm{C}$ under vacuum for $4 \mathrm{~h}$ to yield [P $\left.\left.\mathrm{P}_{888}\right]\right][\mathrm{DEHP}]$ as a viscous liquid $(57.0 \mathrm{~g}, 70.8 \mathrm{mmol}$, yield: $93.8 \%)$. The water content of [ $\left.\mathrm{P}_{8888}\right][$ [DEHP] was $0.1 \%$. The decomposition temperature is reported to be $573-623$ $\mathrm{K}$ in air [21].

\section{Experimental procedure}

The mass loss Knudsen effusion experiments were conducted using thermogravimetric analysis (TGA) with an STA 449 F1 Jupiter apparatus from Netzsch Gerätebau GmbH, Selb, Bavaria, Germany. The unit has a $\mathrm{SiC}$ heating element to fix the temperature within an $\mathrm{Al}_{2} \mathrm{O}_{3}$ reaction chamber that can be evacuated down to $4.6 \times 10^{-4} \mathrm{~Pa}$. The samples were placed in a custom alumina crucible manufactured at Machined Ceramics shown in Fig. 2. This type of Knudsen cell is based on a design by Alfred Buchler, has a knife edge orifice $[23,24]$ with the lid and container of roughly equal mass, and is and adapted for the STA 449 F1 Jupiter. The orifice and the sample chamber measure 0.64 $\mathrm{mm}$ and $7.95 \mathrm{~mm}$ respectively.

\section{[Figure 2]}

The mass loss was monitored and recorded in situ with the STA 449 F1 Jupiter microbalance, with a drift of less than $\pm 10 \mu \mathrm{g}$. The temperature was evaluated with a thermocouple (TC), calibrated with an indium melting standard, in close proximity to the sample. All three ILs were first heated and held at $\sim 450 \mathrm{~K}$ for 12 hours at $4.6 \times 10^{-4} \mathrm{~Pa}$ to ensure removal of moisture and volatile impurities before actual vapor pressure data was collected. The measurement results were analyzed using Proteus, the STA 449 F1 Jupiter companion software; an example for $\left[\mathrm{C}_{8} \mathrm{mim}\right]\left[\mathrm{NTf}_{2}\right]$ is given in Fig. 3.

\section{[Figure 3]}

\section{Analysis approach}


The measured vapor pressure $\left(p_{m}\right)$ is related to the mass loss rate $(\dot{m})$ through HertzKnudsen-Langmuir (HKL) equation [23] rearranged into Eqn. 1:

$p_{m}=\frac{\dot{m} \sqrt{2 \pi R T / m w}}{A}+p$

where $m w$ is the molecular weight, $p$ is the partial pressure of the species in outside of the Knudsen cell, $R$ is the ideal gas constant, $T$ is the absolute temperature, and $A$ is the crosssectional area over which the effusing vapors escape.

The $\dot{m}$ value was used together with the $m w, T$, and $A=A_{o}$ to compute $p_{m}$ from Eqn. 1 .

It is not uncommon for some fluids to exhibit a vaporization coefficient, $\alpha$, that departs substantially from unity [25]. While, in these cases, Langmuir experiments give measured vapor pressures $\left(p_{m}\right)$ that are too low, by comparing these results to those obtained from the Knudsen effusion method $\alpha$ for both liquids and solids and, ergo $p_{e}$ can be determined [25]. That approach was adopted here to calculate and characterize $p_{e}$ for $\left[\mathrm{C}_{2} \mathrm{mim}\right]\left[\mathrm{NTf}_{2}\right],\left[\mathrm{C}_{8} \mathrm{mim}\right]\left[\mathrm{NTf}_{2}\right]$, and $\left[\mathrm{P}_{8888}\right][\mathrm{DEHP}]$ with temperature and estimate the enthalpy of vaporization at $298 \mathrm{~K}$ using the Clausius-Clapeyron relation.

Assuming the Clausing factor $(k)$ for the integral cell is unity while using the WhitmanMotzfeld adjustment [23], $p_{e}$ is calculated with Eqn. 2:

$$
p_{e}=p_{m} \times\left(1+\frac{k A_{o}}{\alpha A_{\text {cell }}}-\frac{k A_{o}}{A_{\text {cell }}}\right)
$$

where $A_{\text {cell }}$ is the cross-sectional area of the inner diameter of the cell. Equation 3 is used to estimate $k$ where $l$ and $d$ are the orifice thickness and diameter respectively.

$$
k=0.0849\left(\frac{2 l}{d}\right)^{2}-0.4041\left(\frac{2 l}{d}\right)+0.9898
$$

The $m w$ of the liquid was taken to be that effusing gas molecules assuming congruent vaporization.

A least squares analysis using Eqn. 4 was performed on the data resulting from the measurements in order to derive a relation for $p_{m}$ for Knudsen $\left(p_{K}\right)$ and Langmuir free evaporation $\left(p_{L}\right)$ techniques respectively. 
$\ln p_{m}=A-\frac{B}{T}$

The slopes fit to the Knudsen $\left(-B_{K}\right)$ and the Langmuir $\left(-B_{L}\right)$ data for each IL sometimes varied. For convenience, however, $\alpha$ was calculated with Eqn. 5 using $B_{K}$ for both the $\ln p_{L}$ and $\ln p_{K}$ dependency on $1 / T$; i.e. the $A$ values for $\ln p_{L}$ were recalculated by fixing $B=B_{K}$. The rationale for this is the overall Whtiman-Motzfeld adjustment is less sensitive to changes in $\alpha$ than is $1 / \alpha$ and therefore $\ln p_{K}$ should naturally exhibit more linearity versus reciprocal temperature. Further, there were more measurements made using the Knudsen technique translating into more confidence in the linear regression.

$$
p_{e}=p_{K} \times\left(1+\frac{k A_{o}}{\alpha A_{\text {cell }}}-\frac{k A_{o}}{A_{\text {cell }}}\right)=p_{L} / \alpha
$$

\section{Results}

The experimental procedure and analysis approach described above was first validated using the commercial lubricant Fomblin Y HVAC 18/8; Fig. 4 shows a good fit between the manufacturer (Solvay S.A., Brussels, Belgium) and the data determined in this work. The $\ln p_{e}$ versus reciprocal temperature relationship is plotted in Figs. $5-8$ and in tabular form in Table 1.

\section{[Figure 4]}

\section{[Table 1]}

The coefficients A and B along with the enthalpy and entropy of vaporization computed using Eqns. 6 and 7 are given in Table 2.

$$
\begin{aligned}
& \Delta H_{\text {vap }}=B R \\
& \Delta S_{\text {vap }}=\frac{\Delta H_{v a p}}{T}+R \ln (p(T) / 101325 P a)
\end{aligned}
$$

\section{[Table 2]}

The uncertainty, $u$, was calculated with Eqn. 8 assuming independent random propagation of the errors in $T$ and $\dot{m}$. 


$$
u=\sqrt{\left(\frac{\partial p_{e}}{\partial \dot{m}} u(\dot{m})\right)^{2}+\left(\frac{\partial p_{e}}{\partial T} u(T)\right)^{2}}
$$

The small $u(T)$ proved to have little effect on Eqn. 8 .

\section{[Figure 5]}

The Knudsen number (Kn) is equal to $\lambda / d_{o}$ where $\lambda$ is given by Eqn. 9.

$$
\lambda=\frac{1}{\sqrt{2} \pi\left(N_{A} p_{t o t} / R T\right) D^{2}}
$$

where $N_{A}$ is Avogadro's number, $p_{\text {tot }}$ is the total pressure and $D$ is the atomic or molecular diameter. Here, $D$ was conservatively estimated to b $1 \mathrm{~nm}$.

\section{[Figure 6]}

As a rule, Knudsen measurements give accurate results when $\mathrm{Kn}$ is 8 or greater [23]. For Kn between 0.4 and 8 , an additional $2.5 \%$ was added to the magnitude of $u\left(p_{K}\right)$ [26]. Finally, the uncertainties reported in Table 1 for the natural logarithm of $p_{e}$ are computed using Eqn. 10.

$$
u\left(\ln p_{e}\right)=\sqrt{\left(\frac{u\left(p_{e}\right)}{p_{e}}\right)^{2}}
$$

\section{Discussion}

Zaitsau et al. [2] observed mass loss from vaporization of volatile impurities from $\left[\mathrm{C}_{2} \mathrm{mim}\right]\left[\mathrm{NTf}_{2}\right]$ and $\left[\mathrm{C}_{8} \mathrm{mim}\right]\left[\mathrm{NTf}_{2}\right]$ reporting several days for complete removal at $323-$ $443 \mathrm{~K}$. Therefore $\left[\mathrm{C}_{2} \mathrm{mim}\right]\left[\mathrm{NTf}_{2}\right]$ and $\left[\mathrm{C}_{8} \mathrm{mim}\right]\left[\mathrm{NTf}_{2}\right]$ samples were heated and held at $\sim 450 \mathrm{~K}$ for 3 days primarily to accurately determine the minimum required time needed to accomplish this conditioning or purification step. The removal of impurities was determined to be complete after cessation of a continually decreasing change in $\dot{m}$, i.e. $\dot{m}$ coincident with $p_{e}$ for either pure $\left[\mathrm{C}_{2} \mathrm{mim}\right]\left[\mathrm{NTf}_{2}\right]$ or $\left[\mathrm{C}_{8} \mathrm{mim}\right]\left[\mathrm{NTf}_{2}\right]$. The results of this experiment show different VLE behavior for the $\left[\mathrm{C}_{2} \mathrm{mim}\right]\left[\mathrm{NTf}_{2}\right]$ and $\left[\mathrm{C}_{8} \mathrm{mim}\right]\left[\mathrm{NTf}_{2}\right]$ samples in this work compared to those in $[2,3]$.

It can be seen in Fig. 3 that $\dot{m}$ for $\left[\mathrm{C}_{8} \mathrm{mim}\right]\left[\mathrm{NTf}_{2}\right]$ remains a constant over a period of $\sim 94$ hours at $450.9 \mathrm{~K}$ and $4.6 \times 10^{-4} \mathrm{~Pa}$ suggesting moisture and other volatiles have already been removed during the initial temperature ramp under vacuum. For $\left[\mathrm{C}_{2} \mathrm{mim}\right]\left[\mathrm{NTf}_{2}\right]$, the behavior is the same, exhibiting $\dot{m}$ corresponding to the vapor pressures shown in Fig. 7, for all temperatures from the initial conditioning step up until all the liquid had 
been evaporated. After each run, the residual $\left[\mathrm{C}_{2} \mathrm{mim}\right]\left[\mathrm{NTf}_{2}\right]$ and $\left[\mathrm{C}_{8} \mathrm{mim}\right]\left[\mathrm{NTf}_{2}\right]$ were visually inspected. Both exhibited a tawny hue with brown colored precipitates.

\section{[Figure 7]}

As can be seen in Figs. 6 and $7, p_{e}$ for $\left[\mathrm{C}_{2} \mathrm{mim}\right]\left[\mathrm{NTf}_{2}\right]$ and $\left[\mathrm{C}_{8} \mathrm{mim}\right]\left[\mathrm{NTf}_{2}\right]$ determined from this work are higher than those from both [2] and [3]. For this particular case, a possible explanation is the synthesis route and therefore the types of impurities, not the level, more profoundly affect the vapor pressure. Both $\left[\mathrm{C}_{2} \mathrm{mim}\right]\left[\mathrm{NTf}_{2}\right]$ and $\left[\mathrm{C}_{8} \mathrm{mim}\right]\left[\mathrm{NTf}_{2}\right]$ can be made using either a $\mathrm{Cl}$ or $\mathrm{Br}$ containing precursor. It is unclear how these two ILs were made for the vapor pressure investigations reported by Zaitsau et al. [2] and Emel'yanenko et al. [3], but both studies were conducted using samples that shared a common pedigree. While a color change and the appearance of precipitates for $\left[\mathrm{C}_{2} \mathrm{mim}\right]\left[\mathrm{NTf}_{2}\right]$ and $\left[\mathrm{C}_{8} \mathrm{mim}\right]\left[\mathrm{NTf}_{2}\right]$ was not reported in $[2,3]$ for the residual liquid, Zaitsau et al. [2] did note slight discoloration of the condensate.

\section{[Figure 8]}

In contrast to $\left[\mathrm{C}_{2} \mathrm{mim}\right]\left[\mathrm{NTf}_{2}\right]$ and $\left[\mathrm{C}_{8} \mathrm{mim}\right]\left[\mathrm{NTf}_{2}\right]$, the conditioning step made a significant impact on correctly characterizing the $p_{e}$ as a volatile component, most likely $\mathrm{H}_{2} \mathrm{O}$, was quickly removed early on during the isothermal vacuum treatment at $\sim 450 \mathrm{~K}$ and $4.6 \times 10^{-4} \mathrm{~Pa}$. For the $\left[\mathrm{P}_{8888}\right][\mathrm{DEHP}]$, little to no observable color change was associated with the IL after the measurements. This IL showed the least reproducibility when comparing the mass loss at similar isotherms during heating to those during cooling steps. While this behavior is generally always present, it led to deviations of up to two orders of magnitude. Further, the trend is reversed in $\left[\mathrm{C}_{8} \mathrm{mim}\right]\left[\mathrm{NTf}_{2}\right]$ showing decreased mass loss on cooling compared to isotherms during heating suggesting a real phenomenon as opposed to an experimental artifact. The cause of this behavior is unknown and will be the subject of a future investigation.

Both sets of samples for $\left[\mathrm{C}_{2} \mathrm{mim}\right]\left[\mathrm{NTf}_{2}\right]$ and $\left[\mathrm{C}_{8} \mathrm{mim}\right]\left[\mathrm{NTf}_{2}\right]$ from this work and those studied in $[2,3]$ were very pure; therefore, the feedstock material likely plays a role in the VLE of these ILs. This means $\left[\mathrm{C}_{2} \mathrm{mim}\right]\left[\mathrm{NTf}_{2}\right]$ and $\left[\mathrm{C}_{8} \mathrm{mim}\right]\left[\mathrm{NTf}_{2}\right]$ between batches could exhibit different vapor pressure behavior. It is unclear if the situation is the same for $\left[\mathrm{P}_{8888}\right][\mathrm{DEHP}]$ but merits further investigation. When employing ILs for applications critically dependent upon VLE, care should be exercised as the behavior may vary substantially depending not only on the purity of the final product but the precursor used in its synthesis.

\section{Conclusions}

Evaporation behavior is necessary to consider when selecting a lubricant and/or additive for a given application. A material with a lower $p_{e}$ will, in general, experience less operative loss from volatilization, which should, barring other factors, translate into longer lifetimes. Another property influencing evaporation behavior is $\alpha$ which becomes increasingly significant with larger fluid surface areas and gas chamber volumes. These 
factors, $p_{e}$ and $\alpha$, are especially important when lubricants are used in environments with elevated temperatures and/or vacuum conditions, such as space applications for example.

The $p_{e}$ versus $T$ relationship for $\left[\mathrm{P}_{8888}\right][\mathrm{DEHP}]$ compares well to $\left[\mathrm{C}_{8} \mathrm{mim}\right]\left[\mathrm{NTf}_{2}\right]$ but is lower than $\left[\mathrm{C}_{2} \mathrm{mim}\right]\left[\mathrm{NTf}_{2}\right]$ synthesized for this study. The $\alpha$ values are comparable for $\left[\mathrm{P}_{8888}\right][\mathrm{DEHP}]$ and $\left[\mathrm{C}_{2} \mathrm{mim}\right]\left[\mathrm{NTf}_{2}\right]$ but that of $\left[\mathrm{C}_{8} \mathrm{mim}\right]\left[\mathrm{NTf}_{2}\right]$ was determined to be an order of magnitude higher. This suggests that while $\left[\mathrm{C}_{8} \mathrm{mim}\right]\left[\mathrm{NTf}_{2}\right]$ does have a low $p_{e}$, its $\alpha$ could make the IL unsuitable for vacuum applications where large evaporation surfaces might be present. The discrepancies between the $p_{e}$ for $\left[\mathrm{C}_{2} \mathrm{mim}\right]\left[\mathrm{NTf}_{2}\right]$ and $\left[\mathrm{C}_{8} \mathrm{mim}\right]\left[\mathrm{NTf}_{2}\right]$ likely result from differences in synthesis precursors and therefore the types of impurities present.

\section{Acknowledgements}

The author would like to thank Dr. Nathan S. Jacobson of NASA Glenn Research Center and Dr. Barbara J. Frame of Oak Ridge National Laboratory for invaluable guidance as well as the helpful comments and reviews by Dr. Christian Contescu and Mr. Brian Jolly of Oak Ridge National Laboratory. The work was supported by the US Department of Energy, Office of Nuclear Energy Fuel Cycle Research and Development Program. 


\section{References}

[1] Y.U. Paulechka, D.H. Zaitsau, G.J. Kabo, A.A. Strechan, Vapor pressure and thermal stability of ionic liquid 1-butyl-3-methylimidazolium Bis(trifluoromethylsulfonyl)amide, Thermochim. Acta 439 (2005) 158-160.

[2] D.H. Zaitsau, G.J. Kabo, A.A. Strechan, Y.U. Paulechka, A. Tschersich, S.P. Verevkin, A. Heintz, Experimental vapor pressures of 1-alkyl-3-methylimidazolium bis (trifluoromethylsulfonyl) imides and a correlation scheme for estimation of vaporization enthalpies of ionic liquids, The Journal of Physical Chemistry A 110 (2006) 7303-7306. [3] V.N. Emel'yanenko, S.P. Verevkin, A. Heintz, The gaseous enthalpy of formation of the ionic liquid 1-butyl-3-methylimidazolium dicyanamide from combustion calorimetry, vapor pressure measurements, and ab initio calculations, J. Am. Chem. Soc. 129 (2007) 3930-3937.

[4] V.V. Chaban, O.V. Prezhdo, Ionic and molecular liquids: working together for robust engineering, The journal of physical chemistry letters 4 (2013) 1423-1431.

[5] X. Wang, Y. Chi, T. Mu, A review on the transport properties of ionic liquids, Journal of Molecular Liquids 193 (2014) 262-266.

[6] P.A. Hunt, C.R. Ashworth, R.P. Matthews, Hydrogen bonding in ionic liquids, Chem. Soc. Rev. 44 (2015) 1257-1288.

[7] J. Holbrey, K. Seddon, Ionic liquids, Clean Products and Processes 1 (1999) 223-236. [8] S.R. Isaacs, E.C. Cutler, J.-S. Park, T.R. Lee, Y.-S. Shon, Synthesis of tetraoctylammonium-protected gold nanoparticles with improved stability, Langmuir 21 (2005) 5689-5692.

[9] F.S. Oliveira, M.G. Freire, M.J. Pratas, J. Pauly, J.L. Daridon, I.M. Marrucho, J.A. Coutinho, Solubility of Adamantane in Phosphonium-Based Ionic Liquids $\dagger$, Journal of Chemical \& Engineering Data 55 (2009) 662-665.

[10] T. Torimoto, T. Tsuda, K.i. Okazaki, S. Kuwabata, New frontiers in materials science opened by ionic liquids, Adv Mater 22 (2010) 1196-1221.

[11] M. Součková, J. Klomfar, J. Pátek, Surface tension and 0.1 MPa densities of imidazolium-, pyridinium-, pyrrolidinium-, and piperidinium-based tris (pentafluoroethyl) trifluorophosphate ionic liquids, Fluid Phase Equilib. 333 (2012) 3846.

[12] A. Rout, J. Kotlarska, W. Dehaen, K. Binnemans, Liquid-liquid extraction of neodymium (III) by dialkylphosphate ionic liquids from acidic medium: the importance of the ionic liquid cation, Physical Chemistry Chemical Physics 15 (2013) 16533-16541. [13] A.F. Shestakov, D.V. Konarev, S.V. Simonov, S.S. Khasanov, A.N. Lapshin, N.F. Goldshleger, Structure and spectral properties of fullerene-tetraoctylammonium bromide composition in neutral and ionic states: experimental data and theoretical analysis, RSC Advances 3 (2013) 8341-8350.

[14] T. Yamaguchi, S. Koda, Dielectric and shear relaxations of ionic liquid composed of symmetric ions, The Journal of chemical physics 141 (2014) 144503.

[15] A. Bhattacharjee, J.A. Lopes-da-Silva, M.G. Freire, J.A. Coutinho, P.J. Carvalho, Thermophysical properties of phosphonium-based ionic liquids, Fluid Phase Equilib. 400 (2015) 103-113.

[16] N.A. Andreeva, V.V. Chaban, Electrostatic charge confinement using bulky tetraoctylammonium cation and four anions, Chem. Phys. Lett. 649 (2016) 44-47. 
[17] M. Bier, S. Dietrich, Vapour pressure of ionic liquids, Mol. Phys. 108 (2010) 211214.

[18] J. Qu, W.C. Barnhill, H.M. Luo, H.M. Meyer, D.N. Leonard, A.K. Landauer, B. Kheireddin, H. Gao, B.L. Papke, S. Dai, Synergistic Effects Between PhosphoniumAlkylphosphate Ionic Liquids and Zinc Dialkyldithiophosphate (ZDDP) as Lubricant Additives, Adv Mater 27 (2015) 4767-4774.

[19] W.C. Barnhill, H. Gao, B.A. Kheireddin, B.L. Papke, H. Luo, B.H. West, J. Qu, Tribological Bench and Engine Dynamometer Tests of a Low Viscosity SAE 0W-16 Engine Oil Using a Combination of Ionic Liquid and ZDDP as Anti-wear Additives, Frontiers in Mechanical Engineering 1 (2015).

[20] P. Bonhote, A.P. Dias, N. Papageorgiou, K. Kalyanasundaram, M. Gratzel, Hydrophobic, highly conductive ambient-temperature molten salts, Inorg. Chem. 35 (1996) 1168-1178.

[21] W.C. Barnhill, J. Qu, H.M. Luo, H.M. Meyer, C. Ma, M.F. Chi, B.L. Papke, Phosphonium-Organophosphate Ionic Liquids as Lubricant Additives: Effects of Cation Structure on Physicochemical and Tribological Characteristics, ACS Appl Mater Inter 6 (2014) 22585-22593.

[22] H.M. Luo, S. Dai, P.V. Bonnesen, Solvent extraction of Sr2+ and Cs+ based on room-temperature ionic liquids containing monoaza-substituted crown ethers, Anal. Chem. 76 (2004) 2773-2779.

[23] E.H. Copland, N.S. Jacobson, Measuring Thermodynamic Properties of Metals and Alloys, Mass Spectrometry Handbook 1143-1180.

[24] A. Booth, T. Markus, G. McFiggans, C. Percival, M. Mcgillen, D. Topping, Design and construction of a simple Knudsen Effusion Mass Spectrometer (KEMS) system for vapour pressure measurements of low volatility organics, Atmospheric Measurement Techniques 2 (2009) 355-361.

[25] G. Pound, Selected values of evaporation and condensation coefficients for simple substances, J. Phys. Chem. Ref. Data 1 (1972) 135-146.

[26] J. Drowart, C. Chatillon, J. Hastie, D. Bonnell, High-temperature mass spectrometry: Instrumental techniques, ionization cross-sections, pressure measurements, and thermodynamic data (IUPAC Technical Report), Pure Appl. Chem. 77 (2005) 683-737. 
Table 1. Natural logarithm of the equilibrium vapor pressures with temperature for the fluids studied in this work.

\begin{tabular}{|c|c|c|c|c|}
\hline Material & Method & $10^{3} \mathrm{~K} / \mathrm{T}$ & $\ln \mathrm{p} / \mathrm{Pa}$ & $\mathrm{u}(\ln \mathrm{p} / \mathrm{Pa})$ \\
\hline$\left[\mathrm{P}_{8888}\right][\mathrm{DEHP}]$ & Knudsen & 2.33 & -4.04 & $1.2 \mathrm{E}-01$ \\
\hline$\left[\mathrm{P}_{8888}\right][\mathrm{DEHP}]$ & Knudsen & 2.44 & -5.71 & $6.3 \mathrm{E}-01$ \\
\hline$\left[\mathrm{P}_{8888}\right][\mathrm{DEHP}]$ & Knudsen & 2.28 & -3.44 & 6.7E-02 \\
\hline$\left[\mathrm{P}_{8888}\right][\mathrm{DEHP}]$ & Knudsen & 2.22 & -3.02 & $4.4 \mathrm{E}-02$ \\
\hline$\left[\mathrm{P}_{8888}\right][\mathrm{DEHP}]$ & Knudsen & 2.17 & -2.33 & $2.3 \mathrm{E}-02$ \\
\hline$\left[\mathrm{P}_{8888}\right][\mathrm{DEHP}]$ & Knudsen & 2.12 & -1.72 & $1.2 \mathrm{E}-02$ \\
\hline$\left[\mathrm{P}_{8888}\right][\mathrm{DEHP}]$ & Knudsen & 2.07 & -2.03 & $9.3 \mathrm{E}-03$ \\
\hline$\left[\mathrm{P}_{8888}\right][\mathrm{DEHP}]$ & Knudsen & 2.12 & -2.92 & $8.2 \mathrm{E}-03$ \\
\hline$\left[\mathrm{P}_{8888}\right][\mathrm{DEHP}]$ & Knudsen & 2.17 & -3.69 & $1.7 \mathrm{E}-02$ \\
\hline$\left[\mathrm{P}_{8888}\right][\mathrm{DEHP}]$ & Knudsen & 2.22 & -4.35 & 4.1E-02 \\
\hline$\left[\mathrm{P}_{8888}\right][\mathrm{DEHP}]$ & Knudsen & 2.28 & -5.11 & $8.8 \mathrm{E}-02$ \\
\hline$\left[\mathrm{P}_{8888}\right][\mathrm{DEHP}]$ & Langmuir & 2.34 & -4.68 & $2.78 \mathrm{E}-02$ \\
\hline$\left[\mathrm{P}_{8888}\right][\mathrm{DEHP}]$ & Langmuir & 2.29 & -4.10 & $1.57 \mathrm{E}-02$ \\
\hline$\left[\mathrm{P}_{8888}\right][\mathrm{DEHP}]$ & Langmuir & 2.23 & -3.53 & $9.05 \mathrm{E}-03$ \\
\hline$\left[\mathrm{P}_{8888}\right][\mathrm{DEHP}]$ & Langmuir & 2.07 & -1.93 & $1.89 \mathrm{E}-03$ \\
\hline$\left[\mathrm{C}_{2} \mathrm{mim}\right]\left[\mathrm{NTf}_{2}\right]$ & Knudsen & 2.38 & -1.55 & $1.25 \mathrm{E}-02$ \\
\hline$\left[\mathrm{C}_{2} \mathrm{mim}\right]\left[\mathrm{NTf}_{2}\right]$ & Knudsen & 2.20 & 0.14 & $2.74 \mathrm{E}-02$ \\
\hline$\left[\mathrm{C}_{2} \operatorname{mim}\right]\left[\mathrm{NTf}_{2}\right]$ & Knudsen & 2.16 & 0.27 & $2.71 \mathrm{E}-02$ \\
\hline$\left[\mathrm{C}_{2} \operatorname{mim}\right]\left[\mathrm{NTf}_{2}\right]$ & Knudsen & 2.11 & 0.44 & $2.68 \mathrm{E}-02$ \\
\hline$\left[\mathrm{C}_{2} \mathrm{mim}\right]\left[\mathrm{NTf}_{2}\right]$ & Knudsen & 2.07 & 0.70 & 2.64E-02 \\
\hline$\left[\mathrm{C}_{2} \mathrm{mim}\right]\left[\mathrm{NTf}_{2}\right]$ & Knudsen & 2.11 & 0.36 & $2.70 \mathrm{E}-02$ \\
\hline$\left[\mathrm{C}_{2} \operatorname{mim}\right]\left[\mathrm{NTf}_{2}\right]$ & Knudsen & 2.79 & -5.91 & 2.09E-01 \\
\hline$\left[\mathrm{C}_{2} \operatorname{mim}\right]\left[\mathrm{NTf}_{2}\right]$ & Langmuir & 2.79 & -5.91 & $2.09 \mathrm{E}-01$ \\
\hline$\left[\mathrm{C}_{2} \mathrm{mim}\right]\left[\mathrm{NTf}_{2}\right]$ & Langmuir & 2.59 & -4.92 & $8.03 \mathrm{E}-02$ \\
\hline$\left[\mathrm{C}_{2} \mathrm{mim}\right]\left[\mathrm{NTf}_{2}\right]$ & Langmuir & 2.24 & -0.33 & 8.75E-04 \\
\hline$\left[\mathrm{C}_{2} \operatorname{mim}\right]\left[\mathrm{NTf}_{2}\right]$ & Langmuir & 2.35 & -1.76 & $3.60 \mathrm{E}-03$ \\
\hline$\left[\mathrm{C}_{2} \mathrm{mim}\right]\left[\mathrm{NTf}_{2}\right]$ & Langmuir & 2.29 & -0.99 & $1.67 \mathrm{E}-03$ \\
\hline$\left[\mathrm{C}_{2} \mathrm{mim}\right]\left[\mathrm{NTf}_{2}\right]$ & Langmuir & 2.10 & 1.21 & $1.95 \mathrm{E}-04$ \\
\hline$\left[\mathrm{C}_{8} \mathrm{mim}\right]\left[\mathrm{NTf}_{2}\right]$ & Knudsen & 2.22 & -3.74 & $8.28 \mathrm{E}-02$ \\
\hline$\left[\mathrm{C}_{8} \mathrm{mim}\right]\left[\mathrm{NTf}_{2}\right]$ & Knudsen & 2.16 & -2.83 & $3.39 \mathrm{E}-02$ \\
\hline$\left[\mathrm{C}_{8} \mathrm{mim}\right]\left[\mathrm{NTf}_{2}\right]$ & Knudsen & 2.11 & -2.26 & $1.93 \mathrm{E}-02$ \\
\hline$\left[\mathrm{C}_{8} \mathrm{mim}\right]\left[\mathrm{NTf}_{2}\right]$ & Knudsen & 2.07 & -1.65 & $1.05 \mathrm{E}-02$ \\
\hline$\left[\mathrm{C}_{8} \mathrm{mim}\right]\left[\mathrm{NTf}_{2}\right]$ & Knudsen & 2.03 & -0.74 & $4.29 \mathrm{E}-03$ \\
\hline$\left[\mathrm{C}_{8} \mathrm{mim}\right]\left[\mathrm{NTf}_{2}\right]$ & Knudsen & 2.07 & -1.34 & 7.79E-03 \\
\hline$\left[\mathrm{C}_{8} \mathrm{mim}\right]\left[\mathrm{NTf}_{2}\right]$ & Knudsen & 2.12 & -1.77 & $1.18 \mathrm{E}-02$ \\
\hline$\left[\mathrm{C}_{8} \mathrm{mim}\right]\left[\mathrm{NTf}_{2}\right]$ & Knudsen & 2.16 & -1.94 & $1.38 \mathrm{E}-02$ \\
\hline$\left[\mathrm{C}_{8} \operatorname{mim}\right]\left[\mathrm{NTf}_{2}\right]$ & Knudsen & 2.07 & -1.34 & 7.79E-03 \\
\hline$\left[\mathrm{C}_{8} \mathrm{mim}\right]\left[\mathrm{NTf}_{2}\right]$ & Knudsen & 2.12 & -1.77 & $1.18 \mathrm{E}-02$ \\
\hline$\left[\mathrm{C}_{8} \mathrm{mim}\right]\left[\mathrm{NTf}_{2}\right]$ & Knudsen & 2.16 & -1.94 & $1.38 \mathrm{E}-02$ \\
\hline$\left[\mathrm{C}_{8} \mathrm{mim}\right]\left[\mathrm{NTf}_{2}\right]$ & Knudsen & 2.22 & -2.71 & 2.94E-02 \\
\hline$\left[\mathrm{C}_{8} \mathrm{mim}\right]\left[\mathrm{NTf}_{2}\right]$ & Langmuir & 2.39 & -5.18 & $9.26 \mathrm{E}-03$ \\
\hline$\left[\mathrm{C}_{8} \mathrm{mim}\right]\left[\mathrm{NTf}_{2}\right]$ & Langmuir & 2.33 & -4.34 & $4.02 \mathrm{E}-03$ \\
\hline$\left[\mathrm{C}_{8} \mathrm{mim}\right]\left[\mathrm{NTf}_{2}\right]$ & Langmuir & 2.28 & -3.54 & $1.83 \mathrm{E}-03$ \\
\hline$\left[\mathrm{C}_{8} \mathrm{mim}\right]\left[\mathrm{NTf}_{2}\right]$ & Langmuir & 2.22 & -2.99 & $1.07 \mathrm{E}-03$ \\
\hline$\left[\mathrm{C}_{8} \mathrm{mim}\right]\left[\mathrm{NTf}_{2}\right]$ & Langmuir & 2.08 & -1.74 & $3.18 \mathrm{E}-04$ \\
\hline Fomblin Y HVAC 18/8 & Knudsen & 2.99 & -7.39 & $1.96 \mathrm{E}+00$ \\
\hline Fomblin Y HVAC 18/8 & Knudsen & 2.64 & -2.82 & $2.15 \mathrm{E}-02$ \\
\hline Fomblin Y HVAC 18/8 & Knudsen & 2.51 & -1.14 & $4.13 \mathrm{E}-03$ \\
\hline
\end{tabular}


Fomblin Y HVAC 18/8

Fomblin Y HVAC 18/8

Fomblin Y HVAC 18/8

Fomblin Y HVAC 18/8

Fomblin Y HVAC 18/8

Fomblin Y HVAC 18/8

Fomblin Y HVAC 18/8

Fomblin Y HVAC 18/8

Fomblin Y HVAC 18/8

$\begin{array}{lccc}\text { Knudsen } & 2.40 & 0.50 & 8.18 \mathrm{E}-04 \\ \text { Knudsen } & 2.28 & 1.77 & 2.36 \mathrm{E}-04 \\ \text { Knudsen } & 2.40 & -0.34 & 1.89 \mathrm{E}-03 \\ \text { Knudsen } & 2.51 & -2.22 & 1.21 \mathrm{E}-02 \\ \text { Langmuir } & 2.83 & -7.22 & 3.28 \mathrm{E}-01 \\ \text { Langmuir } & 2.68 & -3.98 & 1.33 \mathrm{E}-02 \\ \text { Langmuir } & 2.54 & -1.91 & 1.71 \mathrm{E}-03 \\ \text { Langmuir } & 2.42 & -0.57 & 4.60 \mathrm{E}-04 \\ \text { Langmuir } & 2.31 & 0.41 & 1.76 \mathrm{E}-04\end{array}$


Table 2. Thermodynamic parameters for vapor liquid equilibrium of the ILs investigated in this study as well as the Fomblin Y HVAC $18 / 8$ used as a standard.

\begin{tabular}{ccccccc}
\hline Material & $\langle\mathrm{T}\rangle / \mathrm{K}$ & $\mathrm{A}$ & $\mathrm{B} \times 10^{-3} / \mathrm{K}$ & $\Delta \mathrm{H}_{\mathrm{vap}}^{\langle T\rangle} / \mathrm{kJ} \cdot \mathrm{mole}^{-1}$ & $\Delta \mathrm{S}_{\mathrm{vap}}^{\langle\mathrm{T}\rangle} / \mathrm{J} \cdot \mathrm{K}^{-1} \mathrm{~mole}^{-1}$ & $\alpha^{\langle\mathrm{T}\rangle}$ \\
\hline$\left[\mathrm{P}_{8888}\right][\mathrm{DEHP}]$ & 455.7 & $19.7 \pm 1.6$ & $10.4 \pm 1.6$ & $86.52 \pm 13.3$ & $67.78 \pm 28.4$ & 0.047 \\
{$\left[\mathrm{C}_{2}\right.$ mim] $]\left[\mathrm{NTf}_{2}\right]$} & 438.3 & $21.9 \pm 10.6$ & $10.1 \pm 1.3$ & $83.68 \pm 10.8$ & $86.52 \pm 10.7$ & 0.022 \\
{$\left[\mathrm{C}_{8}\right.$ mim $]\left[\mathrm{NTf}_{2}\right]$} & 459.5 & $21.6 \pm 1.96$ & $11.1 \pm 0.9$ & $92.43 \pm 7.5$ & $83.48 \pm 16.4$ & 0.231 \\
Fomblin standard & 388.9 & $32.60 \pm 2.2$ & $13.61 \pm 0.9$ & $113.18 \pm 7.5$ & $175.19 \pm 18.17$ & 0.013
\end{tabular}


Figure 1. Structure of the ILs investigated in this work.

$\left[\mathrm{C}_{2} \operatorname{mim}\right]\left[\mathrm{NTf}_{2}\right]$



$\left[\mathrm{C}_{8} \operatorname{mim}\right]\left[\mathrm{NTf}_{2}\right]$

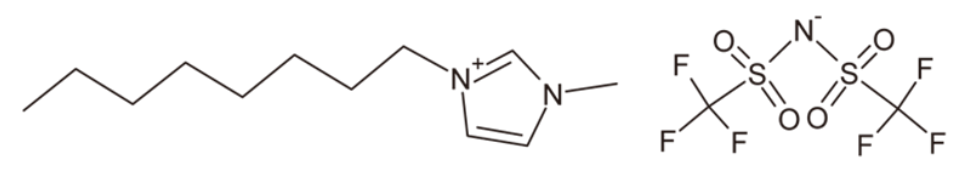

[P8888][DEHP]




Figure 2. Diagram of the Knudsen cell used for the effusion measurements.

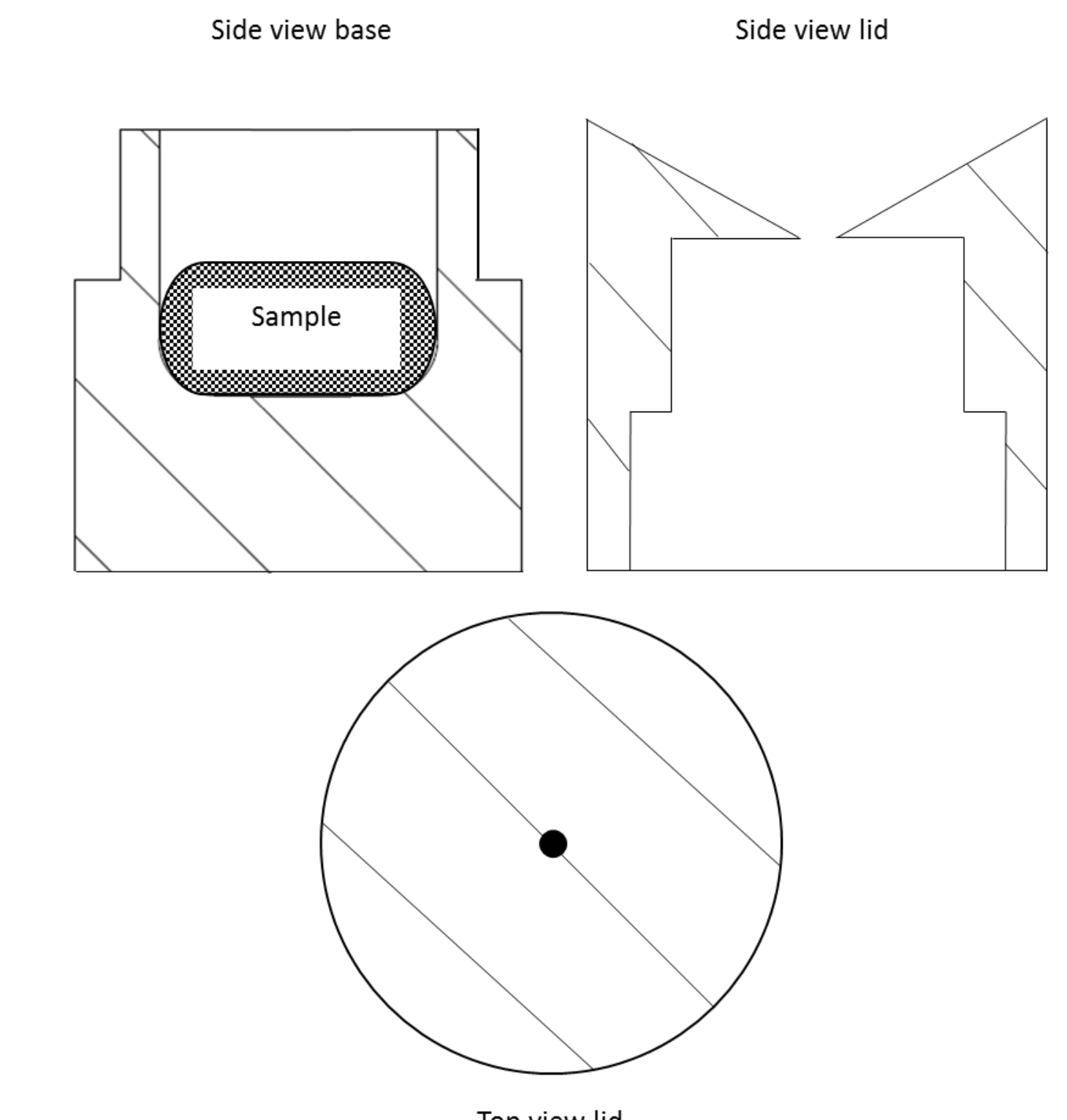

Top view lid 
Figure 3. Recorded mass (solid) and temperature (dashed) curves for a typical Knudsen measurement, in this case for $\left[\mathrm{C}_{8} \mathrm{mim}\right]\left[\mathrm{NTf}_{2}\right]$. The inset corresponds to the shaded area and shows the mass loss per hour at each isotherm.

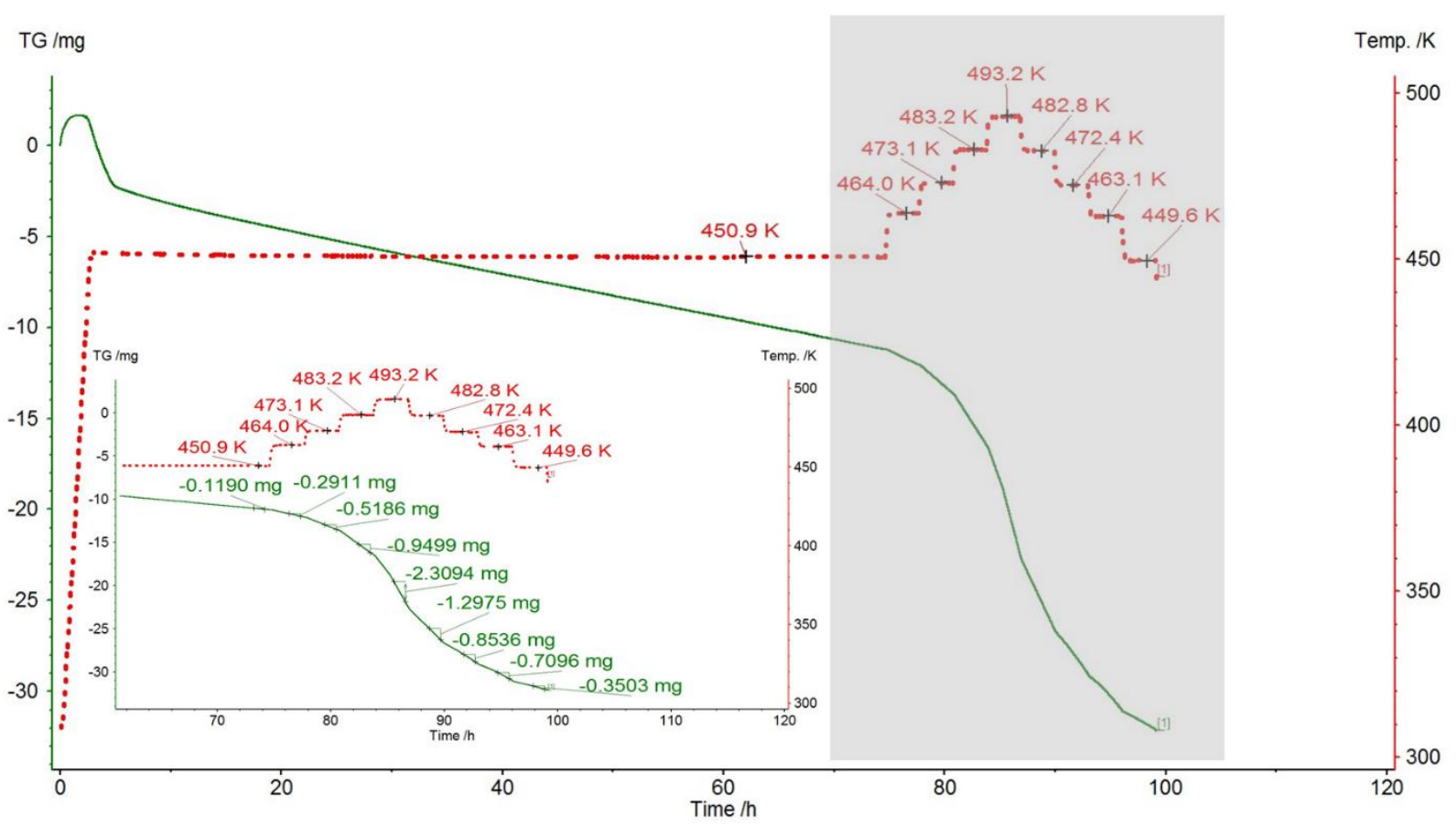


Figure 4. .

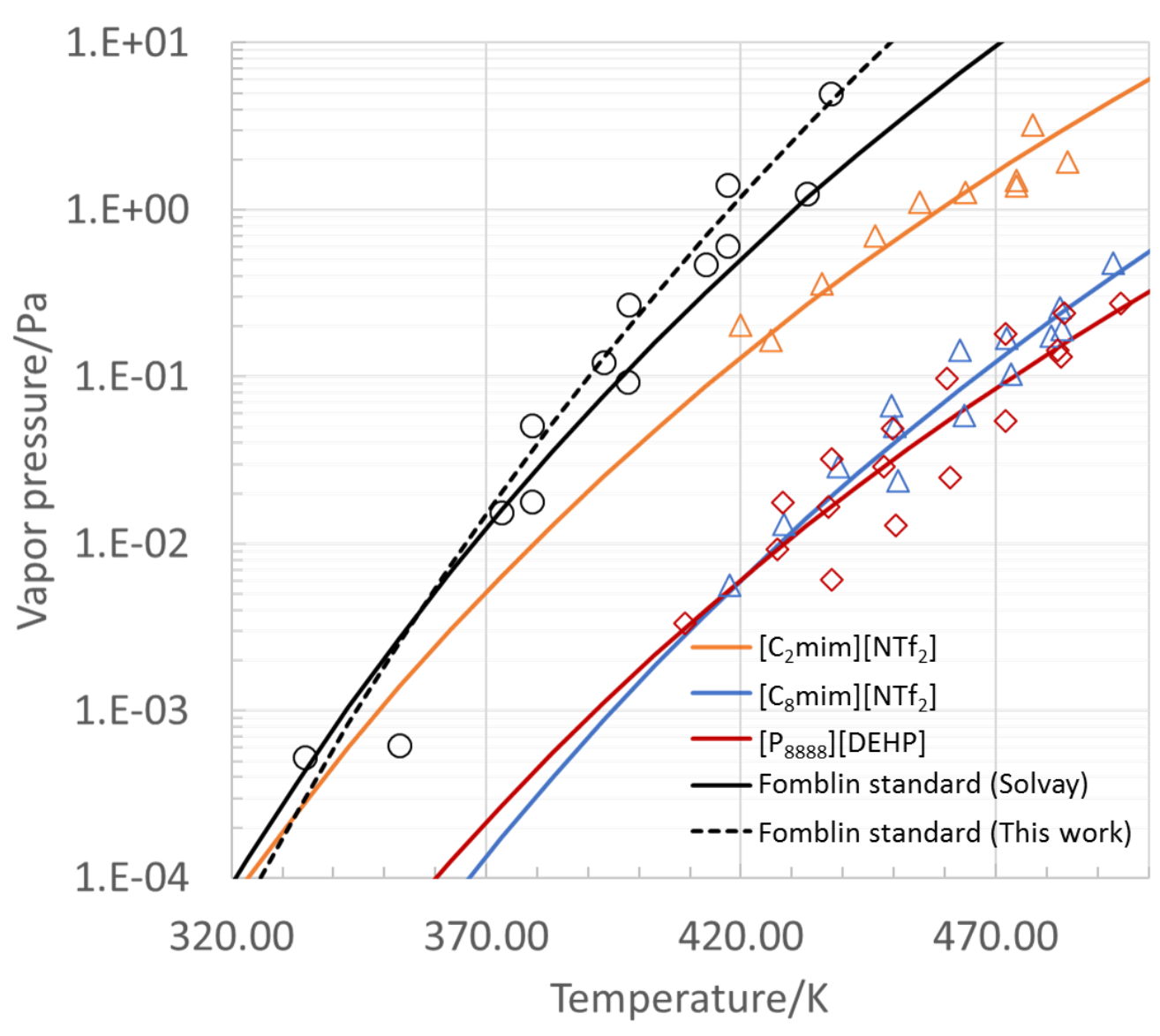


Figure 5. Vapor pressure versus temperature plot (line) for Fomblin Y HVAC 18/8. Error bars are given in (a) for the three data points exhibiting the largest estimated uncertainty for reference. The residuals associated with each measurement are given in (b).

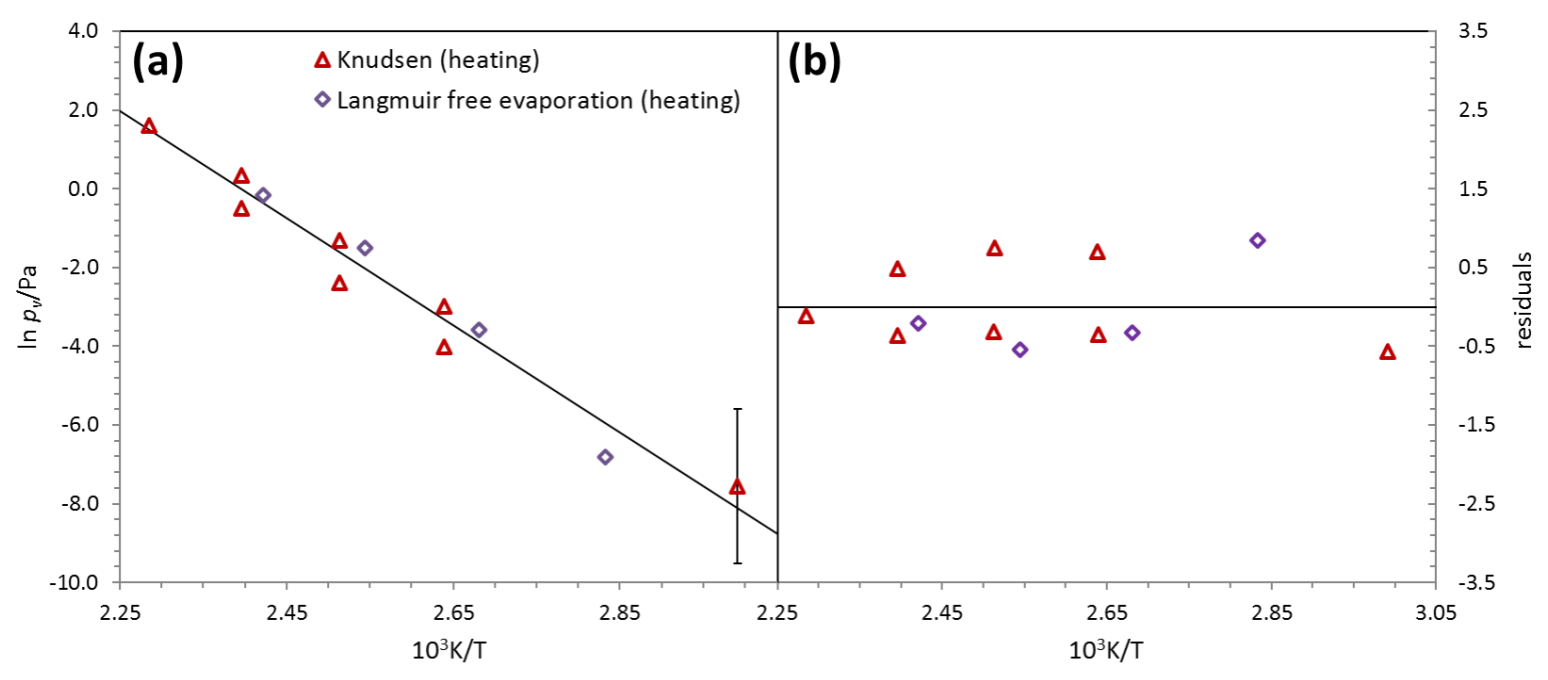


Figure 6. Least squares fit of the natural logarithm of the vapor pressure versus reciprocal temperature for $\left[\mathrm{C}_{8} \mathrm{mim}\right]\left[\mathrm{NTf}_{2}\right]$ using the combined Knudsen effusion and Langmuir free evaporation methods (a) and the residuals associated with each measurement (b).




Figure 7. Least squares fit of the natural logarithm of the vapor pressure versus reciprocal temperature for $\left[\mathrm{C}_{2}\right.$ mim $]\left[\mathrm{NTf}_{2}\right]$ using the combined Knudsen effusion and Langmuir free evaporation methods (a) and the residuals associated with each measurement (b).




Figure 8. Least squares fit of the natural logarithm of the vapor pressure versus reciprocal temperature for $\left[\mathrm{P}_{8888}\right][\mathrm{DEHP}]$ using the combined Knudsen effusion and Langmuir free evaporation methods (a) and the residuals associated with each measurement (b).

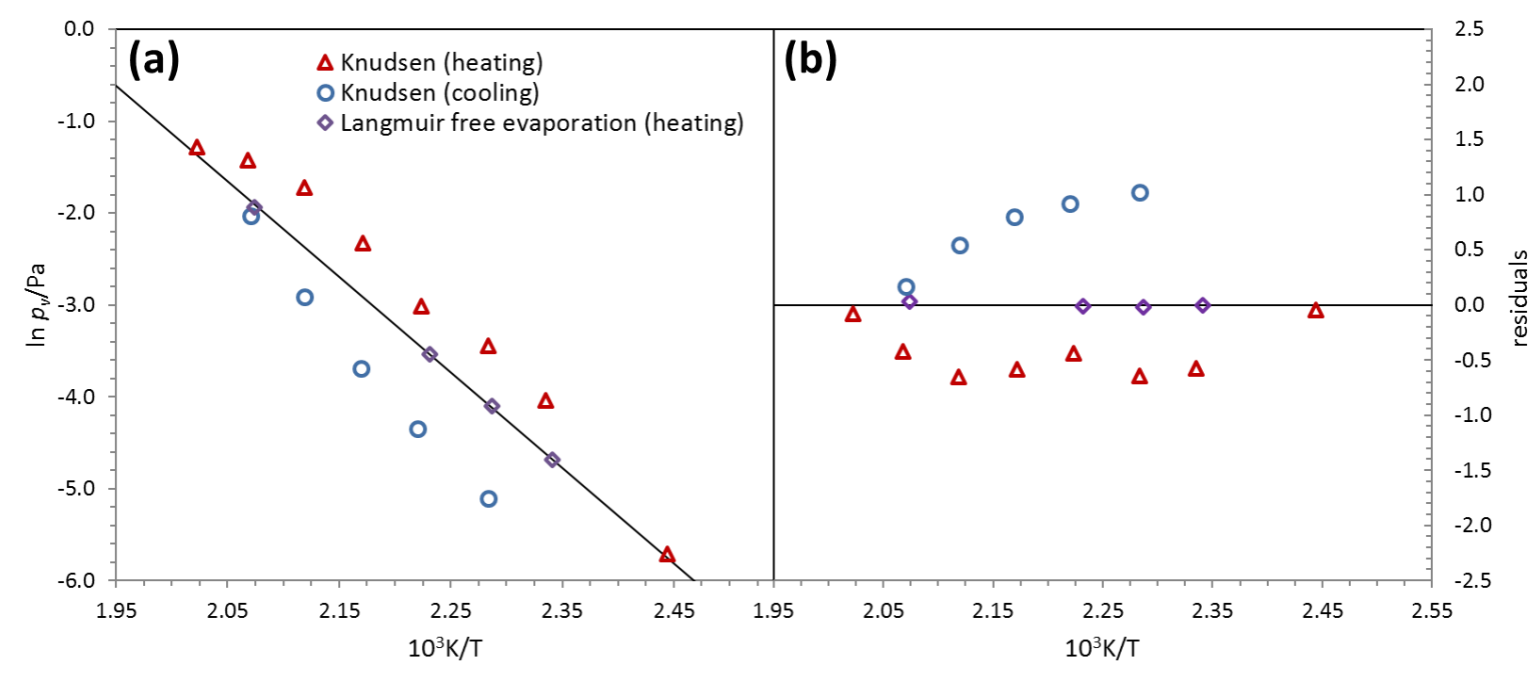


Side view base



Side view lid

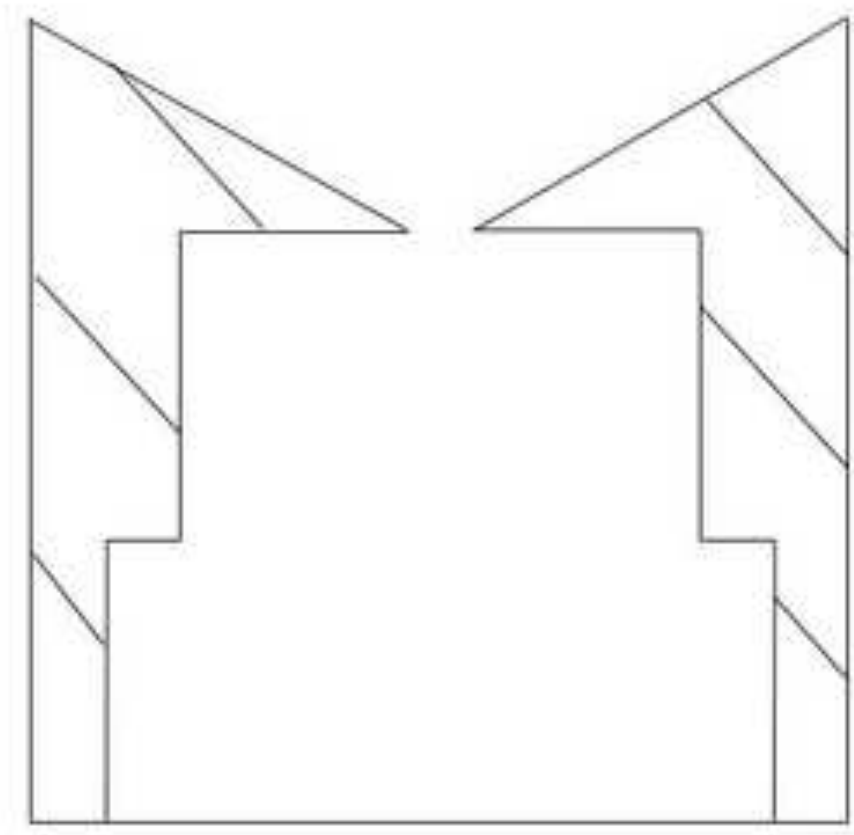



Top view lid 